\title{
Rhizobacteria isolated from a metal-polluted area enhance plant growth in zinc and cadmium-contaminated soil
}

\author{
S. I. A. Pereira $\cdot$ L. Barbosa $\cdot$ P. M. L. Castro
}

Received: 23 September 2013/Revised: 28 March 2014/ Accepted: 10 May 2014/Published online: 4 June 2014

(C) Islamic Azad University (IAU) 2014

\begin{abstract}
In this work, we evaluated the ability of rhizobacteria isolated from a metal-contaminated site to produce plant growth-promoting substances, such as indole-3acetic acid (IAA), ammonia, hydrogen cyanide, siderophores and extracellular enzymes, to solubilize phosphate and for 1-aminocyclopropane-1-carboxylate (ACC)-deaminase activity, while assessing their capacity to enhance Trifolium repens growth. The rhizobacteria that better performed were used as bioinoculants for plants grown in zinc- and cadmium-spiked soils. Rhizobacteria were inoculated onto white clover seedlings growing in 250 and $500 \mathrm{mg} \mathrm{kg}-1$ of zinc and in 10 and $30 \mathrm{mg} \mathrm{kg}^{-1}$ of cadmium-spiked soils and plant traits determined. The available and exchangeable rhizosphere metal concentrations were analyzed. Twenty rhizobacteria stimulated white clover growth under axenic conditions. Overall, strains Rhodococcus erythropolis EC 34, Achromobacter $\mathrm{sp} .1 \mathrm{AP} 2$ and Microbacterium sp. 3ZP2 increased clover biomass in the absence and in presence of metals; however, in soils with $250 \mathrm{mg} \mathrm{kg}^{-1}$ of zinc, bacterial inoculation did not enhance plant biomass. Biomass enhancement may be related to the multiple bacterial promoting traits, especially the production of high levels of IAA and siderophores and the activity of ACC-deaminase. To the best of our knowledge, this is the first study reporting the potential of $R$. erythropolis to increase plant growth in metal-contaminated soils. In general, strains Microbacterium sp. 3ZP2 and Arthrobacter sp. EC 10 enhanced the available and
\end{abstract}

\footnotetext{
S. I. A. Pereira - L. Barbosa · P. M. L. Castro $(\square)$

CBQF - Centro de Biotecnologia e Química Fina - Laboratório

Associado, Escola Superior de Biotecnologia, Universidade

Católica Portuguesa/Porto, Rua Dr. António Bernardino

Almeida, 4200-072 Porto, Portugal

e-mail: plcastro@porto.ucp.pt
}

exchangeable metal concentrations in rhizosphere showing their potential to improve phytoremediation efficiency. This work clearly indicates that rhizobacteria are promising for the development of bioinoculants useful for phytoremediation of polluted soils.

Keywords Heavy metals · Plant growth promotion . Rhizobacteria - White clover

\section{Introduction}

Soil contamination with heavy metals has become one of the most severe environmental hazards. Anthropogenic activities such as mining, smelting, combustion of fossil fuel and sewage sludge have polluted extensive areas throughout the world (Tsezos 2009). High levels of metals not only decrease soil microbial activity and crop production, but also threaten human health since they are able to enter the food chain, increasing the risk of transfer to food products (Boyd 2010).

Biological remediation of polluted sites has received much attention worldwide as a method for improving soil quality by removing metals from soils (Marques et al. 2009). Phytoremediation is among these techniques offering significantly more benefits than conventional cleanup technology (Pilon-Smits 2005). However, the slow growth and low biomass of plants in metal-contaminated soils may limit the efficiency of phytoremediation ( $\mathrm{Li}$ and Ramakrishna 2011; Ma et al. 2011). Moreover, the metal bioavailability in rhizosphere soil is considered to be another critical factor that determines the efficiency of metal translocation and phytostabilization process (Ma et al. 2011). In recent years, several chemical amendments, such as EDTA, have been used to enhance either phytoextraction 
or phytostabilization process (Barrutia et al. 2010). However, chelators may be toxic to plants and to soil microorganisms (Evangelou et al. 2007; Ultra et al. 2005). A promising alternative is the utilization of plant-microbe interactions to improve the efficiency of phytoremediation, altering the mobility and bioavailability of metals in soils (Glick 2010; Ma et al. 2011; Rajkumar et al. 2010).

The results of several studies have demonstrated that plant-associated microorganisms contribute to the uptake of metals by plants and improve plant growth under metal exposure (Andreazza et al. 2010; Dell'Amico et al. 2008; Ma et al. 2009a; Madhaiyan et al. 2007; Sheng and Xia 2006). Thus, the interactions between plants and beneficial rhizosphere microorganisms may be a key element of any phytoremediation technology (Andreazza et al. 2010; Glick 2010). Among the rhizosphere microorganisms involved in heavy metal phytoremediation, the plant growth-promoting rhizobacteria (PGPR) deserve special attention. PGPR are a heterogeneous group of rhizospheric bacteria able to aggressively colonize plant roots and improve the extent or quality of plant growth (Kloepper and Schroth 1978).

Plant growth-promoting rhizobacteria accelerate nutrient availability and assimilation and suppress the deleterious effects of phytopathogenic microorganisms. PGPR can stimulate plant growth by direct mechanisms which include the biological nitrogen fixation, the production of phytohormones (auxins, gibberellins and cytokines), ammonia $\left(\mathrm{NH}_{3}\right)$ and siderophores and the solubilization of phosphate (Gupta et al. 2002; Vessey 2003; Zaidi and Khan 2007). Moreover, some PGPR have the enzyme 1-aminocyclopropane-1-carboxylate (ACC)-deaminase, which hydrolyze ACC, the immediate precursor of ethylene in plants, lowering ethylene level and thus its inhibitory effect on plant growth (Glick 2005). The indirect promotion occurs when the rhizobacteria decrease or prevent the deleterious effects of pathogenic microorganisms (Penrose and Glick 2003). This process is accomplished by the production of antagonistic substances such as antibiotics; antifungal metabolites (e.g., hydrogen cyanide- $\mathrm{HCN}$ ); and extracellular enzymes (Glick 2001; van Loon 2007).

Trifolium repens is one of the most important forage legume species worldwide, and it has been used as an indicator plant in several studies due to its high sensitivity to organic and inorganic compounds (Aina et al. 2006; Vasseur et al. 1998). However, most of the studies on $T$. repens growing in metal-polluted areas have been focused on the symbiotic nitrogen fixation (Broos et al. 2004; Castro et al. 2003; Chaudri et al. 2008), and little attention has been paid to the effect of PGPR on the growth of white clover in metal-contaminated soils. The objectives of this study were to test the ability of several PGPR previously isolated from a heavy metal-contaminated site in Estarreja, Northern Portugal, to produce plant growth- promoting substances, such as indole-3-acetic acid (IAA), $\mathrm{NH}_{3}, \mathrm{HCN}$, siderophores and extracellular enzymes (lipases, cellulases, proteases, pectinases), to solubilize phosphate and ACC-deaminase activity and to assess the PGPR potential to promote Trifolium repens growth under axenic conditions. The rhizobacteria that better performed were selected to evaluate their effect on the enhancement of white clover growth promotion in plants grown in metalspiked soils, as possible bioinoculants to assist phytoremediation processes. Zinc $(\mathrm{Zn})$ and cadmium $(\mathrm{Cd})$ were the chosen metals to carry out this study since $\mathrm{Zn}$ is present at very high concentrations in Estarreja region and $\mathrm{Cd}$ is often associated with $\mathrm{Zn}$ in metal-polluted soils.

\section{Materials and methods}

\section{Bacterial strains}

The bacterial strains used in this study were indigenous from a heavy metal-contaminated site located in Northern Portugal-Esteiro de Estarreja. The site has a long history of metal contamination, due to the industrial activity in the surrounding area. The concentrations of heavy metals in the area reach hazardous levels. Average levels of $835 \mathrm{mg} \mathrm{Pb} \mathrm{kg}{ }^{-1}$, $66 \mathrm{mg} \mathrm{Hg} \mathrm{kg}{ }^{-1}, 3,620 \mathrm{mg} \mathrm{Zn} \mathrm{kg}{ }^{-1}, 26 \mathrm{mg} \mathrm{Cr} \mathrm{kg}{ }^{-1}, 37 \mathrm{mg}$ $\mathrm{Ni} \mathrm{kg}-1$ and 16,800 $\mathrm{mg} \mathrm{Fe} \mathrm{kg}^{-1}$ were measured for the site (Oliveira et al. 2001).

In a previous work, we carried out an extensive characterization and identification through 16S rRNA, of the microbial communities presented in the rhizosphere of several thriving plants growing in this area. Partial sequence of the 16S rRNA gene of bacterial strains was obtained using universal primers 27F (5'-GAGTTTGATCCTGGCTCAG-3') and 1492R (5'-ACCTTGTTACGACTT- $3^{\prime}$ ). The values of $16 \mathrm{~S}$ rRNA gene sequence similarity between the bacterial strains and the closest relative were generally high (97-100 \%) (Pires 2010). For the present work, we selected 32 bacterial strains based on their high tolerance to metals ( $\mathrm{Zn}$ and $\mathrm{Cd}$ ) in trypticase soy agar (TSA) medium. In general, these isolates tolerate up to $500 \mathrm{mg} \mathrm{l}^{-1}$ of $\mathrm{Cd}$ and $1,000 \mathrm{mg} \mathrm{l}^{-1}$ of $\mathrm{Zn}$ (Pires 2010).

Evaluation of plant growth promotion abilities

\section{Production of indole-3-acetic acid (IAA)}

The production of IAA was determined according to the method of Gordon and Weber (1951) with slight modifications. Bacteria were grown overnight in trypticase soy broth (TSB) and then aseptically collected by centrifugation at 9,000 rpm for $10 \mathrm{~min}$. The bacterial pellet was then 
incubated at $30{ }^{\circ} \mathrm{C}$ for 48 and $72 \mathrm{~h}$ with $3 \mathrm{ml}$ of phosphate buffer (pH 7.5) with glucose $(1 \%)$ and $2 \mathrm{ml}$ of L-tryptophan $(1 \%)$. After incubation, $2 \mathrm{ml}$ of $5 \%$ trichloroacetic acid and $1 \mathrm{ml}$ of $0.5 \mathrm{M} \mathrm{CaCl}_{2}$ were added and the mixture was centrifugated at 9,000 rpm for $10 \mathrm{~min}$. The supernatant $(500 \mu \mathrm{l})$ was mixed with $300 \mu \mathrm{l}$ of salper solution ( $2 \mathrm{ml}$ of $0.5 \mathrm{M} \mathrm{FeCl}_{3}$ and $98 \mathrm{ml}$ of $35 \%$ perchloric acid). The absorbance of pink color developed after $30 \mathrm{~min}$ of incubation in the dark was read at $535 \mathrm{~nm}$. The experiments were repeated three times, and IAA determinations were made in triplicate.

\section{ACC-deaminase assay}

The ACC-deaminase activity of cell-free extracts was determined by monitoring the amount of $\alpha$-ketobutyrate generated by the enzymatic hydrolysis of ACC (Saleh and Glick 2001). For determining ACC-deaminase activity, the bacterial cell pellets were washed twice in $5 \mathrm{ml}$ of $0.1 \mathrm{M}$ Tris-HCl, pH 7.6. Then pellets were suspended in $500 \mu \mathrm{l}$ of $0.1 \mathrm{M}$ Tris- $\mathrm{HCl}, \mathrm{pH} 8.5$, and $50 \mu \mathrm{l}$ of toluene was added to the cell suspension and vortexed for $30 \mathrm{~s}$. Two hundred microliter of the toluenized cells was placed in a microcentrifuge tube, and $20 \mu \mathrm{l}$ of $0.5 \mathrm{M}$ ACC was added. The suspension was vortexed and incubated at $30{ }^{\circ} \mathrm{C}$ for $30 \mathrm{~min}$. Following the addition of $1 \mathrm{ml}$ of $0.56 \mathrm{M} \mathrm{HCl}$, the mixture was vortexed and centrifuged for $10 \mathrm{~min}$ at $10,000 \mathrm{rpm}$ at room temperature. Two hundred and fifty milliliter of the supernatant was mixed together with $200 \mu \mathrm{l}$ of $0.56 \mathrm{M} \mathrm{HCl}$. Thereupon, $75 \mu \mathrm{l}$ of the 2,4-dinitrophenylhydrazine (DNPH) reagent $(0.2 \%$ DNPH in $2 \mathrm{M}$ $\mathrm{HCl}$ ) was added, and the mixture was incubated at $30{ }^{\circ} \mathrm{C}$ for $30 \mathrm{~min}$. Following the addition of $500 \mu \mathrm{l}$ of $2 \mathrm{M}$ $\mathrm{NaOH}$, the absorbance of the mixture was measured by using spectrophotometer at $540 \mathrm{~nm}$. The activity of ACCdeaminase was calculated using a calibration curve of pure $\alpha$-ketobutyrate $(0-0.50 \mu \mathrm{M})$. The experiments were repeated three times, and ACC-deaminase determinations were made in triplicate.

\section{Ammonia, siderophores and HCN production}

For assessing the ability to produce ammonia, fresh cultures were inoculated into $10 \mathrm{ml}$ of peptone water and incubated for $48 \mathrm{~h}$ at $30^{\circ} \mathrm{C}$. Then, $500 \mu \mathrm{l}$ of Nessler's reagent (Sigma-Aldrich) was added to each tube. The assay was repeated three times. Development of brown to yellow color was a positive test for ammonia production (Cappuccino and Sherman 1992). Bacterial isolates were screened for the production of siderophores on the chrome azurol S (CAS) agar medium, as described by Schwyn and Neilands (1987). Development of a yellow to orange halo around the bacterial growth after incubation for $48 \mathrm{~h}$ at $30^{\circ} \mathrm{C}$ was considered a positive result for siderophore production. Four plates were made for each strain. The production of $\mathrm{HCN}$ by bacterial isolates was determined by amending TSA medium with $4.4 \mathrm{~g}^{-1}$ of glycine. Strains were streaked on the modified plates, and a Whatman filter paper No.1 soaked in $2 \%$ sodium carbonate prepared in $0.5 \%$ picric acid solution was placed on the top of each of the plates. Plates were incubated at $30{ }^{\circ} \mathrm{C}$ for 4 days after which development of orange to red color indicated $\mathrm{HCN}$ production (Ahmad et al. 2008). Four replicates were made for each bacterial strain.

\section{Phosphate solubilization}

The phosphate solubilizing activity of the strains was analyzed in Institute Phosphate medium (NBRIP) amended with $0.5 \%$ of tricalcium phosphate. The strains were grown at $30{ }^{\circ} \mathrm{C}$ for 10 days (Nautiyal 1999). The presence of a clearing halo around bacterial colonies is indicative for positive phosphate solubilization. Four replicates were made for each bacterial strain.

\section{Production of extracellular enzymes}

Bacterial strains were grown overnight in $10 \mathrm{ml}$ of TSB at $30{ }^{\circ} \mathrm{C}$. The culture was then centrifuged at 9,000 rpm for $10 \mathrm{~min}$. The supernatant was collected and used as enzyme crude extract. Protease production was tested using nutrient agar medium amended with $1 \%$ of skim milk. After 3 days of incubation at $30^{\circ} \mathrm{C}$, a clear zone around the cells indicated positive proteolytic activity (Smibert and Krieg 1994). Cellulase production was determined in carboxymethylcellulose (CMC) agar medium (per liter: $0.5 \mathrm{~g} \mathrm{KH}_{2} \mathrm{PO}_{4}, 0.25 \mathrm{~g} \mathrm{MgSO}_{4} \cdot 7 \mathrm{H}_{2} \mathrm{O}$, $2 \mathrm{~g} \mathrm{CMC}$ disodium salt, $15 \mathrm{~g}$ agar). After 5 days of incubation at $30^{\circ} \mathrm{C}$, CMC plates were flooded with an aqueous solution of Congo red $(1 \% \mathrm{w} / \mathrm{v})$ for $15 \mathrm{~min}$. The Congo red solution was then poured off, and the plates were flooded with $1 \mathrm{M} \mathrm{NaCl}$ for $15 \mathrm{~min}$. A clear halo was considered as positive for cellulase production (Gupta et al. 2012). Pectinase production by the bacterial strains was determined as described by Cattelan et al. (1999). Briefly, M9 medium agar was amended with $10 \mathrm{~g} \mathrm{l}^{-1}$ pectin, $2 \mathrm{~g} \mathrm{l}^{-1}$ glucose plus $1.2 \mathrm{~g} \mathrm{l}^{-1}$ yeast extract. Plates were incubated 3 days at $30{ }^{\circ} \mathrm{C}$ plates and then flooded with Lugol's iodine solution for $10 \mathrm{~min}$. Clear halos around the colonies were considered as positive for pectinase production. The production of lipases was assessed in LB-modified agar medium supplemented with $2.0 \mathrm{~g} \mathrm{l}^{-1}$ of $\mathrm{CaCl}_{2}$ and $10 \mathrm{~g} \mathrm{l}^{-1}$ of Tween-20, Tween-40 and Tween-80 (Smibert and Krieg 1994). All assays were performed in triplicate. 
Influence of PGPR on $T$. repens growth under axenic conditions

This experiment was carried out to screen the PGPR ability to promote $T$. repens growth under axenic conditions. T. repens seeds were surface-sterilized by exposing them $30 \mathrm{~s}$ to $95 \%$ ethanol and $1 \mathrm{~min}$ to $0.5 \%$ (v/v) $\mathrm{NaOCl}$. Then, seeds were washed six times with sterilized distilled water. Seeds were germinated in water agar plates $(15 \%)$ for $24 \mathrm{~h}$. Bacterial strains were grown in TSB broth overnight at $30{ }^{\circ} \mathrm{C}$, after which they were washed and resuspended in saline solution $(0.85 \% \mathrm{NaCl})$ to obtain a final concentration of $10^{8} \mathrm{CFU} \mathrm{ml}{ }^{-1}$. White clover seedlings with 1 day of growth were placed in flasks with Jensen's agar medium (per liter: $0.8 \mathrm{~g} \mathrm{CaCl}_{2}, 0.2 \mathrm{~g} \mathrm{~K}_{2} \mathrm{HPO}_{4}, 0.2 \mathrm{~g}$ $\mathrm{MgSO}_{4} \cdot 7 \mathrm{H}_{2} \mathrm{O}, 0.1 \mathrm{~g} \mathrm{NaCl}, 0.1 \mathrm{~g} \mathrm{FeCl}_{3}, 0.5 \mathrm{~g} \mathrm{KNO}_{3}, 1 \mathrm{ml}$ of micronutrient solution which composition is: per liter, $2.8 \mathrm{~g} \mathrm{H}_{3} \mathrm{BO}_{3}, 1.83 \mathrm{~g} \mathrm{MnSO}_{4} \cdot 4 \mathrm{H}_{2} \mathrm{O}, 0.1 \mathrm{~g} \mathrm{ZnCl}_{2}, 0.091 \mathrm{~g}$

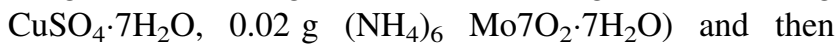
inoculated with $1 \mathrm{ml}$ of a suspension of each bacterial strain. One milliliter of sterilized saline solution was added to the control treatment. The plants were kept in a controlled growth chamber $(12 \mathrm{~h}$ photoperiod, $300 \mu \mathrm{mol}$ $\mathrm{m}^{-2} \mathrm{~s}^{-1}$ photosynthetically active radiation, $22{ }^{\circ} \mathrm{C}$ temperature, $75 \%$ relative humidity). Harvest occurred 6 weeks after the beginning of the experiment. Entire plants were washed with distilled water and divided in roots and shoots, after which root elongation and shoot elongation were registered. The dry biomass of the plants was determined after oven drying at $70{ }^{\circ} \mathrm{C}$ for $48 \mathrm{~h}$.

Seedling length assay in presence of $\mathrm{Zn}$ and $\mathrm{Cd}$

Based on the PGP traits and the ability to increase $T$. repens growth under axenic conditions, four bacterial strains (Rhodococcus erythropolis EC34; Achromobacter sp. 1AP2; Microbacterium sp. 3ZP2 and Arthrobacter sp. EC10) were selected for exploring their potential to promote seedling elongation in the presence of metals. Selected strains were grown in TSB medium for $24 \mathrm{~h}$ at $30{ }^{\circ} \mathrm{C}$ on an orbital shaker. Cells were collected by centrifugation, washed twice with saline solution $(0.85 \% \mathrm{NaCl})$ and suspended in sterile saline solution to obtain the final inoculum density of $10^{8} \mathrm{CFU} \mathrm{ml} \mathrm{m}^{-1}$. Two milliliter of bacterial suspensions or sterile saline solution (uninoculated control) was added to Petri dishes with filter paper. Bacterial suspensions and sterile saline solution were supplemented with 0, 250, 500 and 1,000 $\mathrm{mg} \mathrm{Zn}^{-1}$ and 0, 10, 30, 50 and $100 \mathrm{mg} \mathrm{Cd} 1^{-1}$ supplied as $\mathrm{ZnCl}_{2}$ and $\mathrm{CdCl}_{2} \cdot 2.5 \mathrm{H}_{2} \mathrm{O}$ (Sigma), respectively. Trifolium repens var. Huia seeds were surface-sterilized and aseptically placed on wetted filter paper. Seedlings' length was measured after incubation of the closed Petri dishes for 7 days at $22{ }^{\circ} \mathrm{C}$ (Belimov et al. 2005). The vigor index was determined as follows: $\%$ of germination $\times$ seedling length (Luo et al. 2011).

Pot experiments: T. repens growth under $\mathrm{Zn}$ and $\mathrm{Cd}$ exposure

The experiments for studying the effect of the bacterial strains Rhodococcus erythropolis EC34; Achromobacter sp. 1AP2; Microbacterium sp. 3ZP2 and Arthrobacter sp. EC10 on $T$. repens growth in the presence of different concentrations of $\mathrm{Zn}$ and $\mathrm{Cd}$ were conducted in pots $(5 \mathrm{~cm}$ diameter and $6 \mathrm{~cm}$ high) containing non-spiked or metalspiked soil. The soil used in this study was an agricultural soil from northern Portugal, and the physicochemical properties have been described in detail by Marques et al. (2013). The soil was milled $(2 \mathrm{~mm})$ and sterilized by steaming $\left(120{ }^{\circ} \mathrm{C}\right.$ for $70 \mathrm{~min}$ on two consecutive days and dried in an oven at $40{ }^{\circ} \mathrm{C}$ for 4 days). After sterilization, the soil was artificially contaminated with aqueous solution of $\mathrm{ZnCl}_{2}$ or $\mathrm{CdCl}_{2} \cdot 2.5 \mathrm{H}_{2} \mathrm{O}$ to achieve final concentrations of 250 and $500 \mathrm{mg} \mathrm{Zn} \mathrm{kg}^{-1}$ and 10 and $30 \mathrm{mg} \mathrm{Cd} \mathrm{kg}^{-1}$ dry soil. Soil moisture content was maintained at $60 \%$ of the water holding capacity by adding deionized sterile water. Spiked soils were placed for a period of 6 weeks in the greenhouse undergoing 3 cycles of saturation with water and air drying, favoring the distribution of the metals throughout the entire soil mass and allowing the soil to reach equilibrium between available and organic matter absorbed fractions (Blaylock et al. 1997).

Treatments in the greenhouse included a control (nonspiked soil), 250 and $500 \mathrm{mg} \mathrm{Zn} \mathrm{kg}^{-1}, 10$ and $30 \mathrm{mg} \mathrm{Cd}$ $\mathrm{kg}^{-1}$ spiked soil and five types of inoculation: no bacteria-B0 (uninoculated control), B1 (EC 34), B2 (1AP2), B3 (3ZP2) and B4 (EC 10). T. repens var. Huia seeds were surface-sterilized and germinated in pots with $100 \mathrm{~g}$ of the tested soils. Five pots were used for each treatment. Each pot received six seeds, after germination, seedlings were reduced to four per pot.

For inoculation of the seedlings, bacterial strains were grown overnight in TSB medium at $30{ }^{\circ} \mathrm{C}$. Cells in the exponential phase were harvested by centrifugation at $9,000 \mathrm{rpm}$ for $10 \mathrm{~min}$, washed twice with sterile saline solution $(0.85 \% \mathrm{NaCl})$ and centrifuged again. Bacterial inoculum was prepared by resuspending pelleted cells in sterile saline solution to get an inoculum density of ca. $10^{8}$ CFU ml ${ }^{-1}$. Two days after seedling emergence, the pots were inoculated with $2 \mathrm{ml}$ of a suspension of each bacterial strain. Two milliliter of saline solution (B0) was also added to the control treatment pots (uninoculated). Pots were placed in a controlled growth room (12 h photoperiod, $450 \mu \mathrm{mol} \mathrm{m} \mathrm{s}^{-1}$ photosynthetically active radiation, $18-21{ }^{\circ} \mathrm{C}$ temperature range, $60-75 \%$ relative humidity range) and were watered daily. After 10 weeks, plants were 
removed from the pots and the plant surface was thoroughly washed with tap and deionized water. Then, root elongation and shoot height were registered. Plant dry biomass was determined after shoots, and roots were ovendried at $70{ }^{\circ} \mathrm{C}$ for $72 \mathrm{~h}$. The exchangeable-ethylenediaminetetraacetic acid (EDTA) extractable and availableammonium acetate (NH4-Ac) extractable- $\mathrm{Zn}$ and $\mathrm{Cd}$ fractions were determined for the soils at the end of the experiment. The exchangeable and available $\mathrm{Zn}$ and $\mathrm{Cd}$ fractions were determined using flame atomic absorption spectroscopy (FA-AAS) (Wallinga et al. 1989) in a Unicam 960 spectrophotometer (Waltham, USA).

\section{Statistical analysis}

All statistical analyses were performed using the SPSS 18.0 software package (SPSS Inc., Chicago, IL, USA). The data were analyzed through analysis of variance (ANOVA). To detect the statistical significance of differences $(P<0.05)$ between means, the Duncan and Dunnett's tests were performed.

\section{Results and discussion}

Plant growth-promoting rhizobacteria have gained worldwide importance and acceptance for soil remediation strategies and for agricultural purposes (Saharan and Nehra 2011). PGPR may cause beneficial effects on plant health and growth, through a variety of mechanisms-namely through the increase of nutrient availability and assimilation from the environment, providing the plant with hormones and growth factors or suppress disease-causing microbes (Vessey 2003). In the present study, bacterial strains isolated from a metal-contaminated site showed PGP traits and the ability to enhance $T$. repens growth under axenic conditions. Those traits allowed us to select four rhizobacteria, R. erythropolis EC 34, Achromobacter sp. 1AP2, Microbacterium sp. 3ZP2 and Arthrobacter sp. EC 10, with the ability to enhance white clover growth in $\mathrm{Zn}$ - and Cd-spiked soils, through the increase of root and shoot biomass, and ability to mobilize metals in rhizosphere soils, thus with potential to improve the efficiency of phytoremediation of metal-contaminated soils.

PGP traits and white clover growth promotion under axenic conditions

Twenty bacterial strains significantly increased $T$. repens root biomass production and/or shoot and root elongation when compared to control uninoculated plants (Fig. 1). The root dry biomass of white clover varied from $3.70 \mathrm{mg}$ (plants inoculated with strain EC 6) to $10.09 \mathrm{mg}$ (plants inoculated with strain EC 34) (Fig. 1a) and root and shoot elongation from $4.0 \mathrm{~cm}$ (plants inoculated with strain EC 19) to $14.5 \mathrm{~cm}$ (plants inoculated with strain 3ZP2) and from $5.8 \mathrm{~cm}$ (plants inoculated with strain EC 29) to a $10.3 \mathrm{~cm}$ (plants inoculated with strain EC32), respectively (Fig. 1b, c). Among the twenty bacterial strains which increased white clover growth, the genera Arthrobacter, Rhodococcus, Microbacterium and Pseudomonas genera were well represented. The positive impact of the Pseudomonas strains on plant growth has been reported by several authors, while Arthrobacter, Rhodococcus and Microbacterium strains are not so frequently reported as plant growth-promoting rhizobacteria. Dell'Amico et al. (2008) showed that the inoculation of Brassica napus seeds with P. fluorescens ACCD strain caused a $64 \%$ increase of shoot fresh biomass. Similarly, the Pseudomonas sp. Ps29C strain tested by Rajkumar and Freitas (2008) increased the fresh weight of Indian mustard shoots by $22 \%$. It has been reported that rhizobacteria induces plant growth by contributing to the host plant endogenous pool of phytohormones, such as IAA (Khalid et al. 2004; Patten and Glick 2002). A low level of IAA promotes primary root elongation, whereas a high level stimulates lateral and adventitious root formation (Xie et al. 1996). In this study, all strains were able to synthesize IAA in the presence of the precursor Ltryptophan (Fig. 2). The IAA amounts produced by strains ranged from 2.4 to 63.5 and from 1.4 to $80.1 \mathrm{mg} \mathrm{l}^{-1}$, after 48 and $72 \mathrm{~h}$, respectively (Fig. 2a, b). Strains S3X (70.81 $\mathrm{mg}^{-1}$ ) and EC1B (80.05 $\mathrm{mg} \mathrm{l}^{-1}$ ) belonging to Pseudomonas and Mesorhizobium genera, respectively, produced the highest amounts of IAA. Such high levels of IAA production have been reported before. Farina et al. (2012) reported that 78 bacterial isolates derived from Brassica napus rhizosphere showed IAA levels above $100 \mathrm{mg} \mathrm{l}^{-1}$ and at least one strain from Pseudomonas genus produced $345.7 \mathrm{mg} \mathrm{l}^{-1}$ of IAA. Ma et al. (2009b) also showed that a Psychrobacter strain produced $110 \mathrm{mg}^{-1}$ and several Bacillus strains produced more than $77 \mathrm{mg} \mathrm{l}^{-1}$ of IAA. In this study, several isolates (1 AP2, EC 34, 3ZP2 and EC 10) with high ability to produce IAA promoted white clover root biomass which suggests a relation between both parameters. There results were corroborated by Marques et al. (2010) who reported a positive correlation between IAA-producing rhizobacteria and Zea mays root biomass promotion and by Khalid et al. (2004) who showed that bacterial strains which produced the highest amount of IAA also increased growth of wheat. Promotion of root growth is one of the major markers by which the beneficial effect of PGPR is measured (Glick et al. 1995). Rapid establishment of roots is advantageous for young seedlings as it increases their ability to anchor themselves to the soil and 

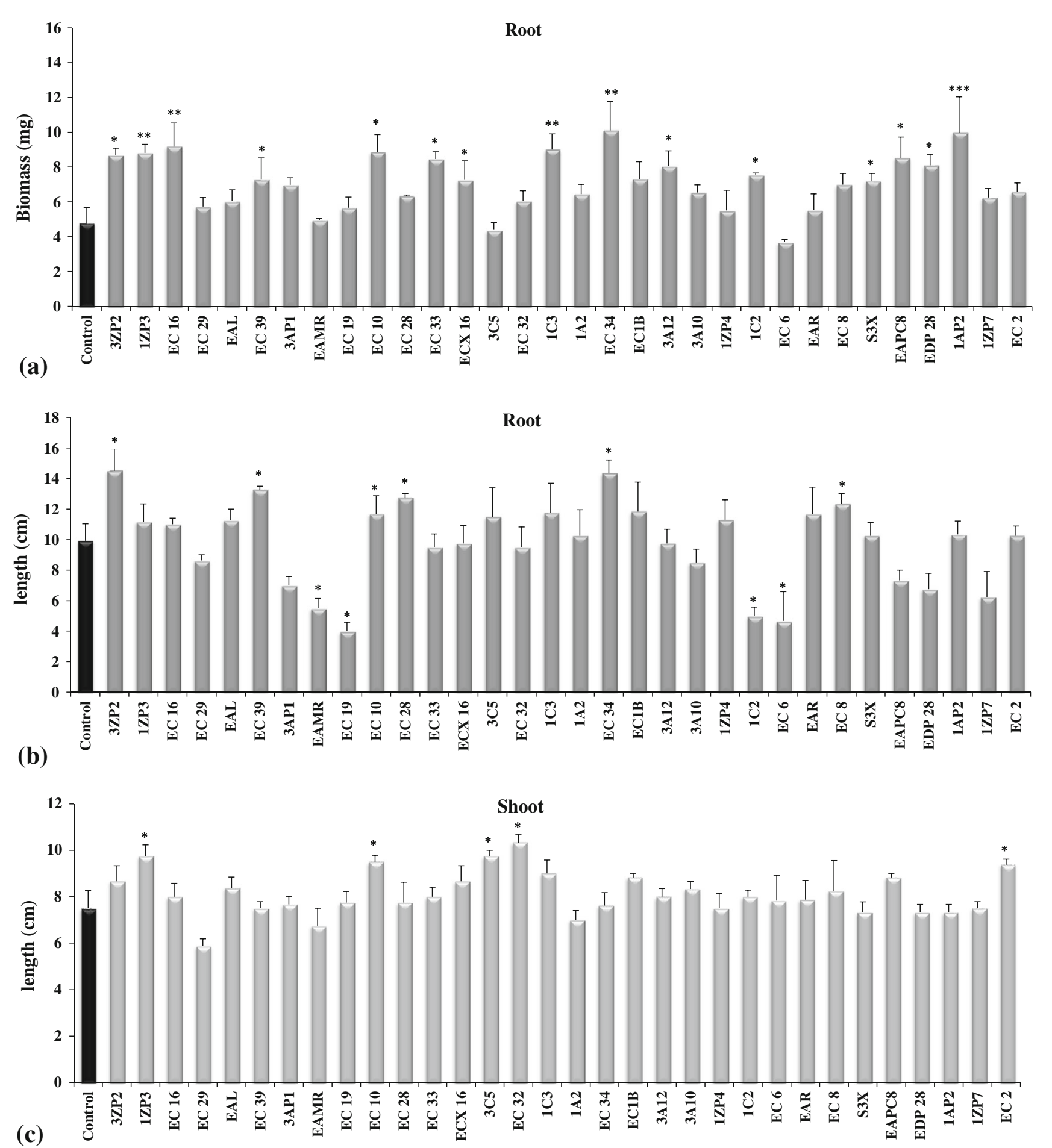

Fig. 1 Influence of PGPR inoculation on root (a) dry biomass (mg) and on root (b) and shoot (c) elongation $(\mathrm{cm})$ of Trifolium repens plants growing under axenic conditions. Results are expressed as mean \pm SE $(n=3-5)$. A one-way ANOVA was performed for each plant section. The test results are shown with the test statistic as:

to obtain water and nutrients from their environment, thus enhancing their probabilities for survival (Patten and Glick 2002). *significant at the level $P<0.05$; **significant at the level $P<0.01$; ***significant at the level $P<0.001$ according to the Dunnett's test. The $F$ value of ANOVA for root biomass is $F=3.293(P<0.001)$ and for root elongation and shoot elongation are $F=5.514$ $(P<0.05)$ and $F=2.751(P<0.05)$, respectively

1-Aminocyclopropane-1-carboxylate-deaminase activity was detected in all rhizobacteria (Fig. 3). The strain EAR from Lysinibacillus genus recorded the highest 

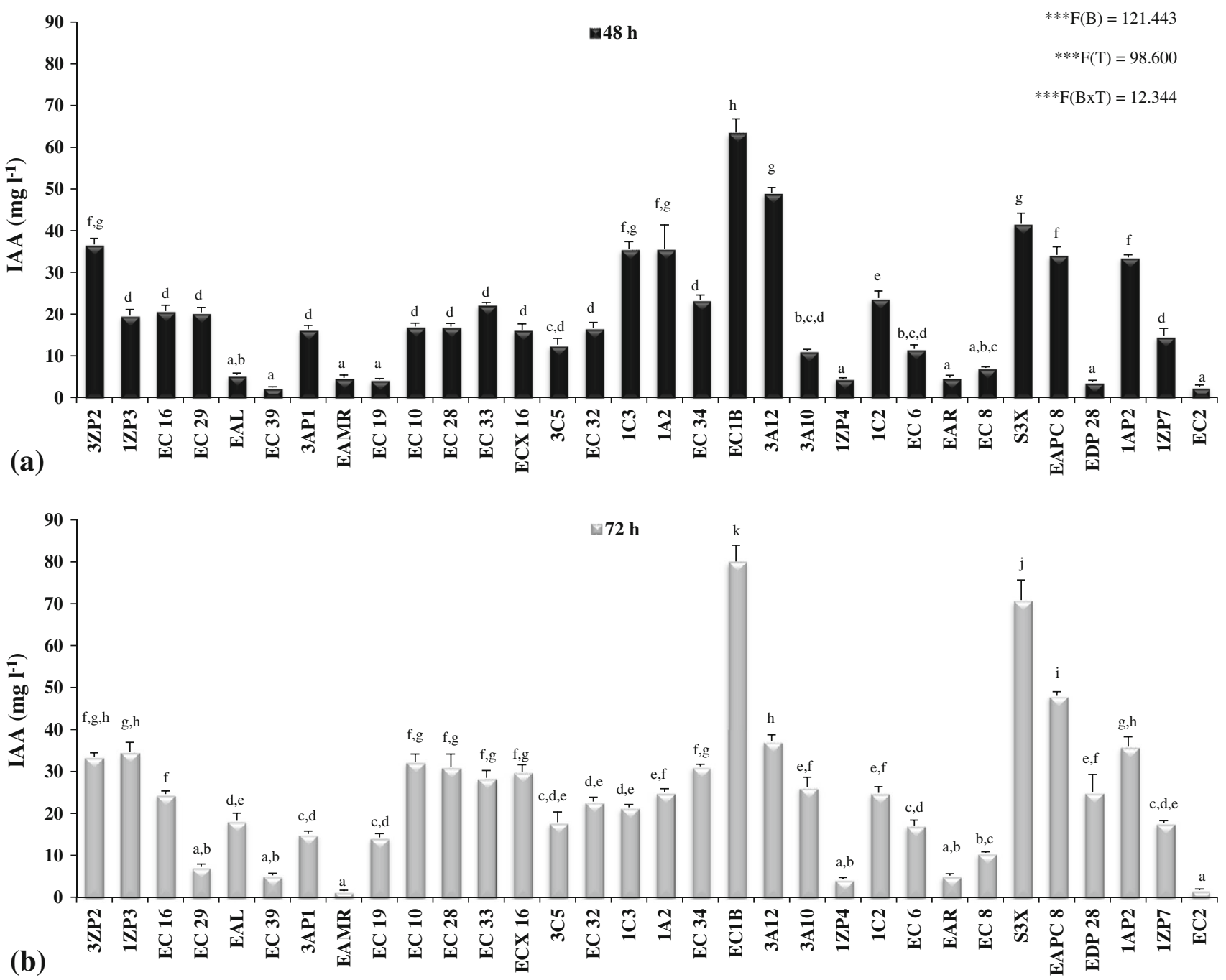

Fig. 2 Production of indole acetic acid (IAA) $\left(\mathrm{mg}^{-1}\right)$ by bacterial strains after $48 \mathrm{~h}(\mathbf{a})$ and $72 \mathrm{~h}$ (b) of incubation. Results are expressed as mean $\pm \operatorname{SE}(n=6-12)$. A two-way ANOVA was performed to determine the influence of the time of incubation (48 and $72 \mathrm{~h}$ ) on IAA production. The test results are shown with the test statistic for each case ( $B$ bacterial isolate, $T$ time of incubation, $B \times T$ bacterial isolates $\times$ time of incubation interaction). $* * *$ Significant at the level

ACC-deaminase activity (6.87 nmoles $\alpha$-ketobutyrate $\mathrm{g}^{-1} \mathrm{~h}^{-1}$ ) followed by strain EAPC8 (5.66 nmoles $\alpha$-ketobutyrate $\mathrm{g}^{-1} \mathrm{~h}^{-1}$ ) from Pseudomonas genus. It was possible to establish a positive trend between plant traits and ACC-deaminase, since several isolates with high ACC-deaminase activity (EC 10, EC 32, EAPC8 and EC 2) enhanced white clover growth by increasing root biomass or shoot elongation. Our results are in agreement with Shahzad et al. (2010), who showed that rhizobacteria having ACC-deaminase were highly effective in improving root and shoot length of chickpea plants. Cattelan et al. (1999) also reported that ACC-deaminase
$P<0.001$. A one-way ANOVA was performed for each time of incubation. Means for the same time of incubation with different letters are significantly different from each other $(P<0.05)$ according to the Duncan test. For 48 and $72 \mathrm{~h}$ of incubation, the $F$ values of one-way ANOVA are $F=68.856(P<0.001)$ and $F=59.328$ $(P<0.001)$, respectively. IAA was never detected in control cultures which were thus not considered for this statistical analysis

rhizobacteria caused early growth in soybean. Ammonia production is another common trait in tested rhizobacteria (Table 1). $\mathrm{NH}_{3}$ production by bacterial isolates may enhance plant growth, which was also seen by Marques et al. (2010) that demonstrated a positive correlation between bacterial ammonia production and root and shoot elongation of Zea mays plants. Only 2 strains (ECX16 and 3C5) belonging to Arthrobacter genus showed ability to solubilize phosphate. The ability of rhizobacteria to convert insoluble phosphorous into soluble forms is an important trait in PGPR for increasing plant yields (Chen et al. 2006). 


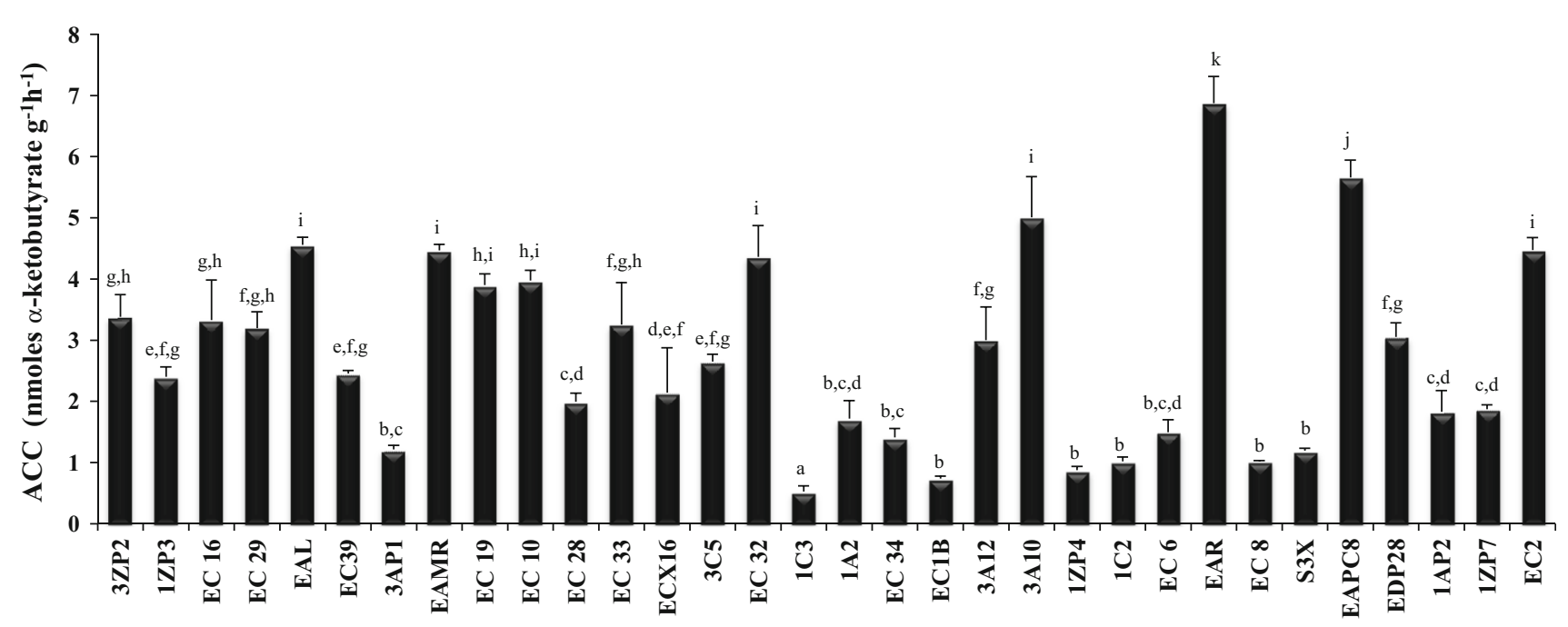

Fig. 3 ACC-deaminase activity (nmoles $\alpha$-ketobutyrate $\mathrm{g}^{-1} \mathrm{~h}^{-1}$ ) of screened isolates. Results are expressed as mean \pm SE $(n=4-8)$. Means with different letters are significantly different from each other
$(P<0.05)$ according to the Duncan test. The $F$ value of one-way ANOVA is $F=27.180(P<0.001)$
Siderophore production was positive in all tested strains (Table 1). More than $55 \%$ of the isolates showed strong or very strong production of siderophores, while only $5.4 \%$ (EAL and 1ZP7) were considered weak siderophore producers. Correlations between siderophore production and plant traits were not significant, probably due the absence of phytopathogenic microorganisms since the plant experiment was performed in aseptic conditions. Several studies demonstrated that siderophore-producing rhizobacteria improve plant growth by increasing iron availability to plants or by limiting iron for phytopathogenic organisms (Sahu and Sindhu 2011). Marques et al. (2010) showed that bacterial siderophore production influenced plant traits, evidencing positive correlations with nutrients assimilation ( $\mathrm{N}$ and $\mathrm{P}$ ) and Z. mays growth. Hydrogen cyanide production is another possible way by which rhizobacteria may suppress plant pathogens. In the present study, $92 \%$ of bacterial isolates were able to produce $\mathrm{HCN}$. Isolates belonging to Arthrobacter, Pseudomonas, Mesorhizobium and Shewanella were among the best HCN-producing strains (Table 1). PGPR may also synthesize extracellular enzymes such as, cellulases, pectinases, proteases and lipases. These bacterial traits will confer significant advantage in the presence of phytopathogens, since their cell walls will be degraded by the extracellular enzymes and their deleterious effects suppressed. In the present work, generally rhizobacteria were able to produce lipase and more than $60 \%$ of rhizobacteria produced protease, while cellulase and pectinase activity were restricted to few bacterial strains (Table 1). The strains EAL (Bacillus sp.) and EC 6 (Alcaligenes sp.) showed positive results for all tested extracellular enzymes, showing their potential to be used on biocontrol of plant pathogens. Correlations between these bacterial traits and plant parameters were not significant, which may be due to the aseptic conditions of the assay. However, these PGP traits should be taken into consideration when considering field applications, as plant resistance will be potentially increased if the associated bacteria produce these compounds.

Influence of PGPR inoculation on plant growth in presence of $\mathrm{Zn}$ and $\mathrm{Cd}$

Based on their PGP traits and on growth promotion of T. repens under axenic conditions, four heavy metal-tolerant rhizobacteria B1 (Rhodococcus erythropolis EC 34), B2 (Achromobacter sp. 1AP2), B3 (Microbacterium sp. 3ZP2) and B4 (Arthrobacter sp. EC 10) were selected for pot experiments. These rhizobacteria showed multiple PGP traits, such as the production of high levels of IAA and siderophores and ACC-deaminase activity. Strains B1 and B3 greatly enhanced root biomass by 112 and $82 \%$ and root elongation by 44 and $46 \%$, respectively, while strains B2 and B4 increased white clover biomass by 109 and $86 \%$, respectively (Fig. 1).

Some of these rhizobacteria were able to improve seedling length of $T$. repens in the absence and in the presence of different levels of $\mathrm{Zn}$ and $\mathrm{Cd}$ contamination (Table 2); however, some significant differences were observed between treatments with different bacterial strains. The rhizobacteria that better performed were strains B1 and B4 for $\mathrm{Zn}$-treated seeds, which increased seedling growth by 64 and $96 \%$, respectively, in the presence of $250 \mathrm{mg} \mathrm{l}^{-1}$ of $\mathrm{Zn}$ and strains B1, B2 and B4 for Cd-treated 


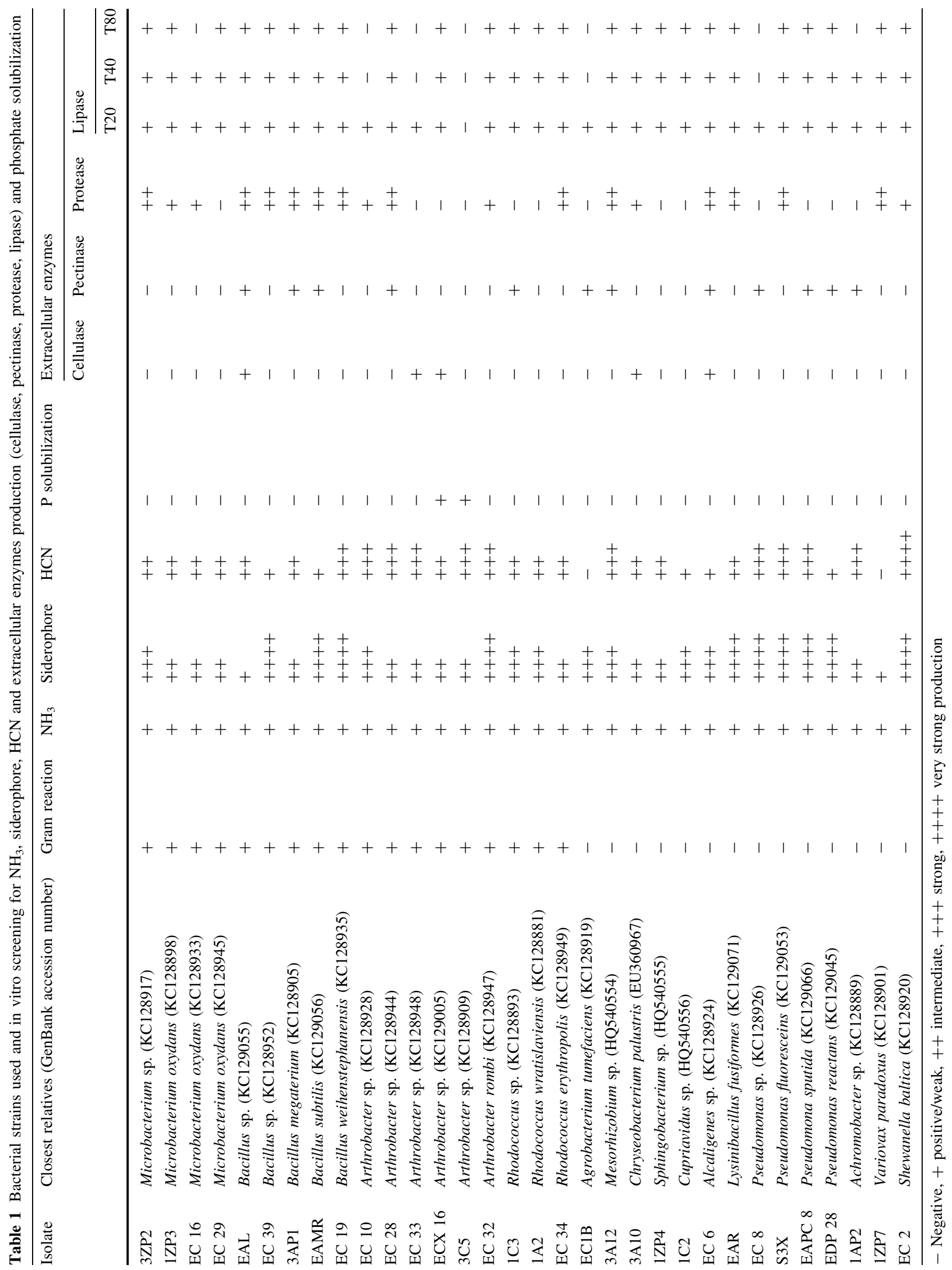




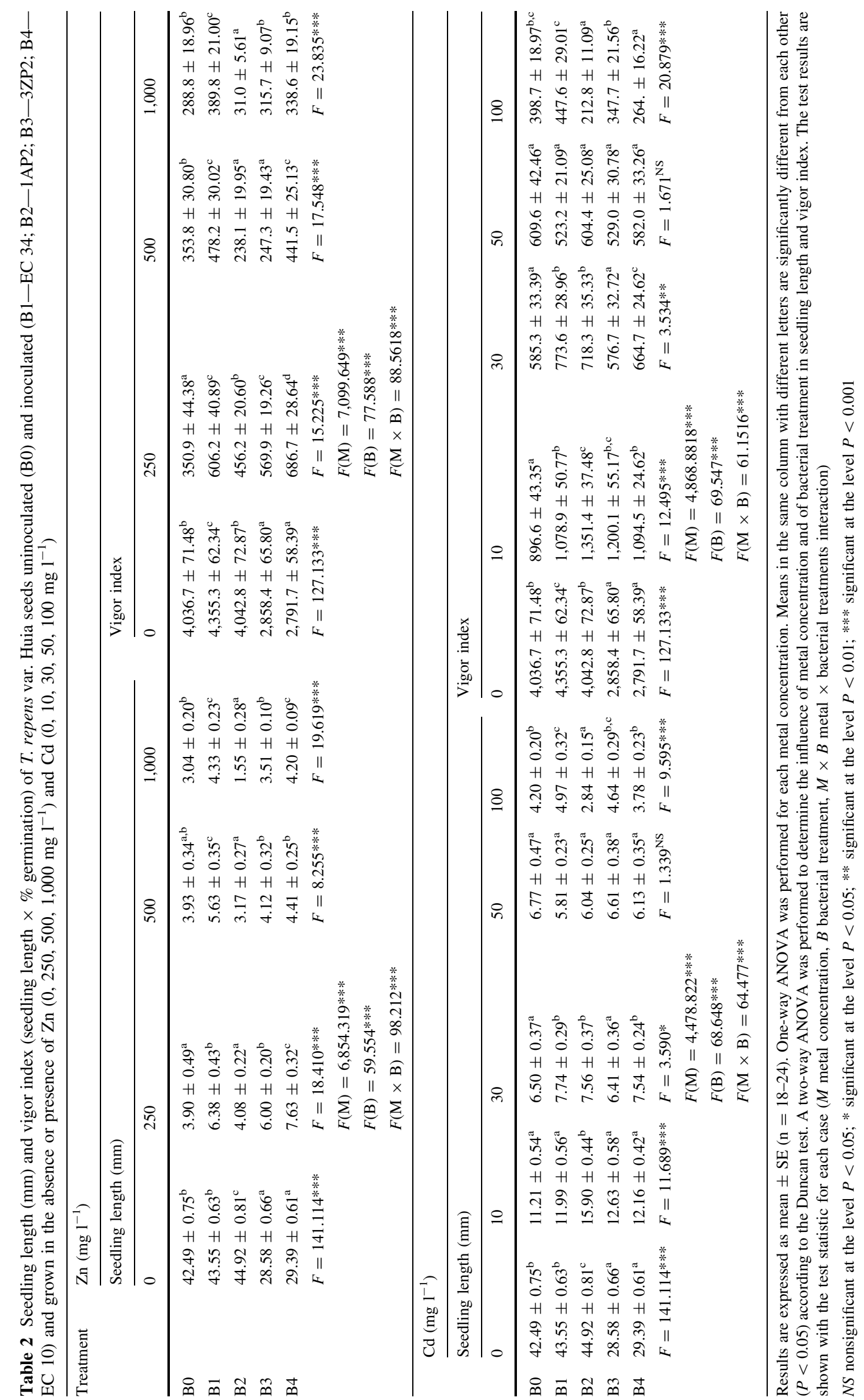



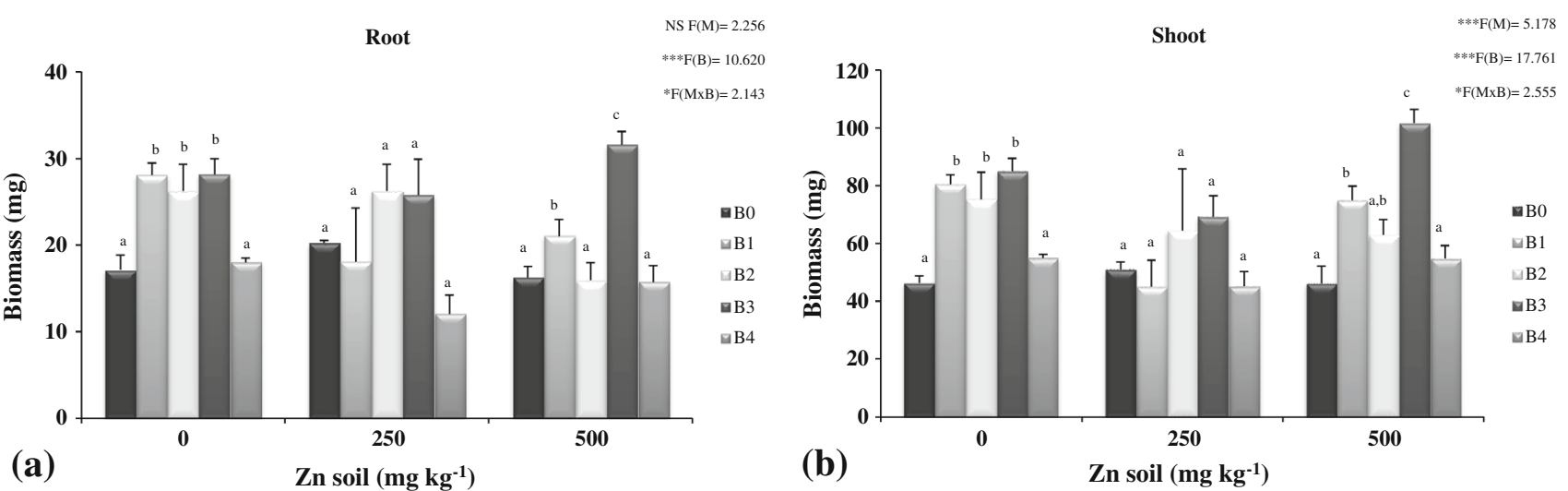

(b)

Zn soil (mg kg-1)
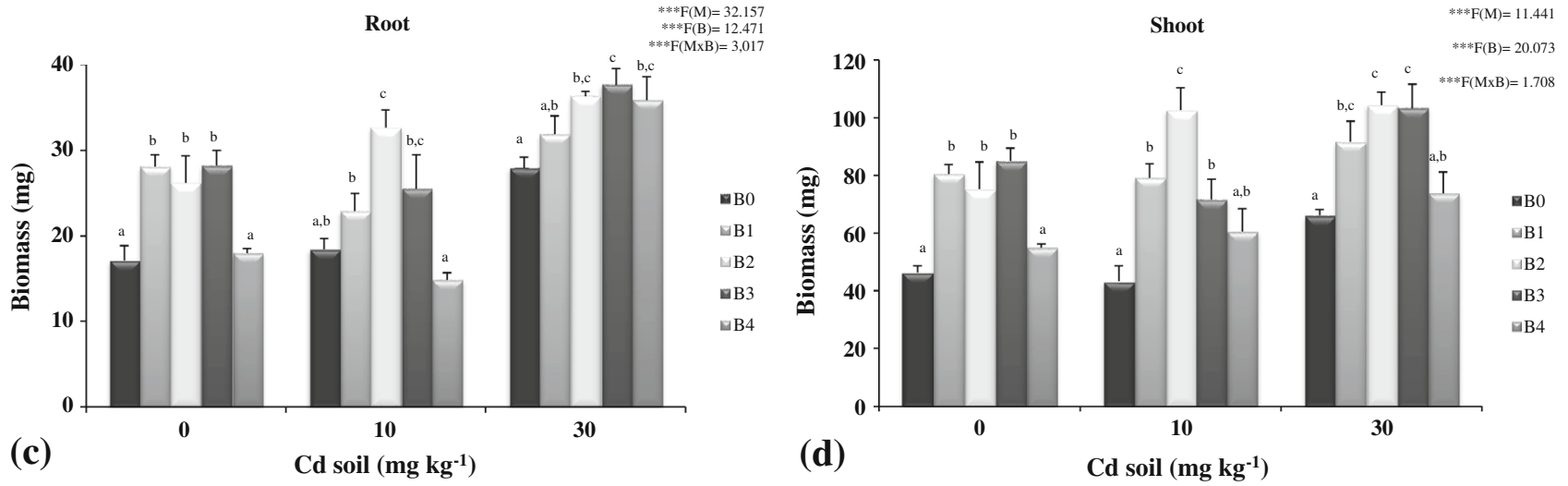

Fig. 4 Trifolium repens shoot and root dry biomass $(\mathrm{mg})$ when exposed to different $\mathrm{Zn}(\mathbf{a}, \mathbf{b})$ and $\mathrm{Cd}(\mathbf{c}, \mathbf{d})$ concentrations $\left(\mathrm{mg} \mathrm{kg}^{-1}\right)$ in the soil. The error bar represents the SE $(n=5-6)$. Two-way ANOVA was performed to determine the influence of soil $\mathrm{Zn}$ and $\mathrm{Cd}$ concentration and of bacterial treatment (B0-uninoculated; B1-EC 34; B2-1AP2; B3-3ZP2; B4-EC 10) in roots and shoots biomass. The test results are shown with the test statistic for each case $(M$ soil metal concentration; $B$ bacterial treatment; $M \times B$ metal $\times$ bacterial treatments interaction). $N S$ nonsignificant at the level $P<0.05$; *significant at the level $P<0.05$; **significant at the level $P<0.01$; ***significant at the level $P<0.001$. One-way ANOVA was performed for each metal concentration in the soil. Means for the

same metal concentration with different letters are significantly different from each other $(P<0.05)$ according to the Duncan test. For the root tissues, the $F$ values of one-way ANOVA are $F=6.446$ $(P<0.001), F=1.240(P>0.05)$ and $F=16.679(P<0.001)$ for 0,250 and $500 \mathrm{mg} \mathrm{Zn} \mathrm{kg}^{-1}$ spiked soils, respectively, and $F=9.150$ $(P<0.001)$ and $F=4.607(P<0.05)$ for 10 and $30 \mathrm{mg} \mathrm{Cd} \mathrm{kg}$ spiked soils, respectively. For the shoot tissues, the $F$ values of oneway ANOVA are $F=7.235(P<0.001), F=1.741(P>0.05)$ and $F=21.052(P<0.001)$ for 0,250 and $500 \mathrm{mg} \mathrm{Zn} \mathrm{kg}^{-1}$ spiked soils, respectively, and $F=10.834(P<0.001)$ and $F=6.00(P<0.01)$ for 10 and $30 \mathrm{mg} \mathrm{Cd} \mathrm{kg}^{-1}$ spiked soils, respectively

seeds, which increased seedling growth in the presence of $30 \mathrm{mg} \mathrm{l}^{-1}$ of $\mathrm{Cd}$. In general, the results obtained for vigor index corroborate the results obtained for the seedling length in the presence of both metals. Belimov et al. (2005) also showed that several metal-tolerant rhizobacteria were capable of stimulating root elongation of B. juncea seedlings either in the presence or absence of toxic $\mathrm{Cd}$ concentrations.

The detrimental effects of metals on plant growth were also reduced by bacterial inoculation, as revealed by the performance of the plants in $\mathrm{Zn}$ - and Cd-spiked soils (Figs. 4, 5). The metal concentrations used in this study are within the range of those considered as of concern by the Dutch standards (targets of $2 \mathrm{mg} \mathrm{Cd} \mathrm{kg}^{-1}$ and $140 \mathrm{mg} \mathrm{Zn}$

$\mathrm{kg}^{-1}$ and intervention levels of $12 \mathrm{mg} \mathrm{Cd} \mathrm{kg}^{-1}$ and $720 \mathrm{mg}$ $\mathrm{Zn} \mathrm{kg}^{-1}$ ) or by the Canadian Soil Quality Guidelines (1.4 to $22 \mathrm{mg} \mathrm{Cd} \mathrm{kg} \mathrm{me}^{-1}$ and 200 to $360 \mathrm{mg} \mathrm{Zn} \mathrm{kg}^{-1}$ ) and the common total metal content in unpolluted-soils which is between 10 and $300 \mathrm{mg} \mathrm{kg}^{-1}$ for $\mathrm{Zn}$ and below $1 \mathrm{mg} \mathrm{kg}^{-1}$ for Cd (Kabata Pendias and Pendias 1992).

In general, increasing metal concentration in the soil exerts a severe effect on root growth (El-Tayeb et al. 2006). In the present work, increasing metal contamination did not reduce white clover biomass and growth (Fig. 4); the study of Manier et al. (2009) also showed that the root development of white clover plants was not significantly affected by $\mathrm{Zn}\left(115-450 \mathrm{mg} \mathrm{kg}^{-1}\right)$ and $\mathrm{Cd}\left(0.63-35 \mathrm{mg} \mathrm{kg}^{-1}\right)$ contamination in soils. 


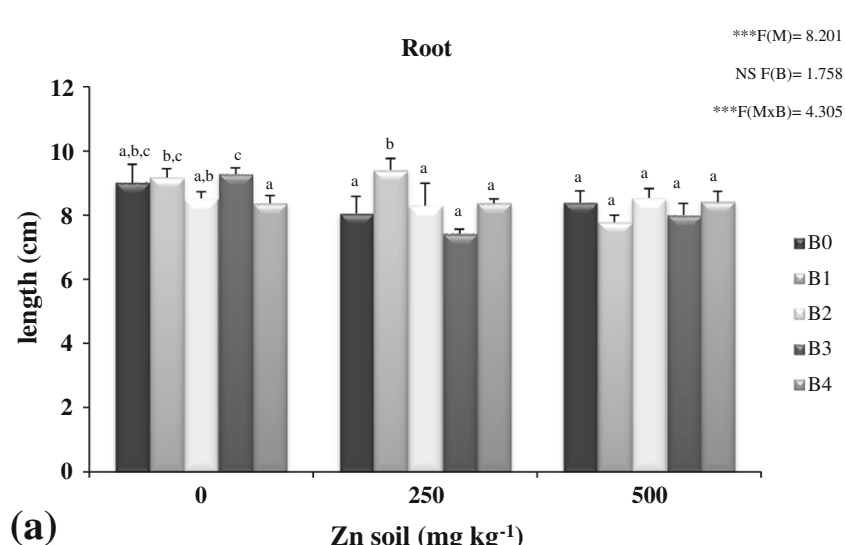

(a)

Zn soil ( $\left.\mathbf{m g ~ k g}^{-1}\right)$

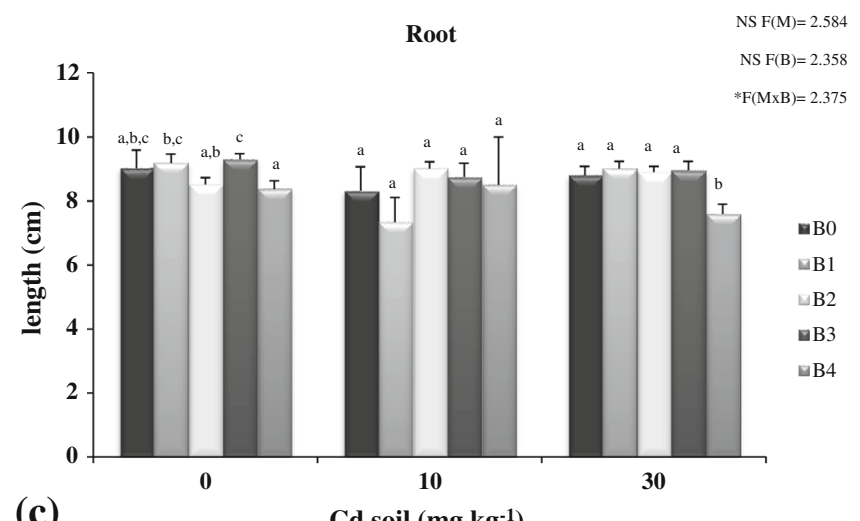

(c)

Cd soil (mg kg-1)

Fig. 5 Trifolium repens shoot and root elongation $(\mathrm{cm})$ when exposed to different $\mathrm{Zn}(\mathbf{a}, \mathbf{b})$ and $\mathrm{Cd}(\mathbf{c}, \mathbf{d})$ concentrations $\left(\mathrm{mg} \mathrm{kg}^{-1}\right)$ in the soil. The error bar represents the SE $(n=15-25)$. Two-way ANOVA was performed to determine the influence of soil $\mathrm{Zn}$ and $\mathrm{Cd}$ concentration and of bacterial treatment (B0-uninoculated; B1-EC 34; B2-1AP2; B3-3ZP2; B4-EC 10) in roots and shoots elongation. The test results are shown with the test statistic for each case $(M$ soil metal concentration, $B$ bacterial treatment; $M \times B$ metal $\times$ bacterial treatments interaction). $N S$ nonsignificant at the level $P<0.05$; *significant at the level $P<0.05$; **significant at the level $P<0.01$; ***significant at the level $P<0.001$. One-way ANOVA was performed for each metal concentration in the soil.

In absence of metals, bacterial inoculation promoted white clover biomass production and growth (Figs. 4, 5). Strains B1, B2 and B3 enhanced root biomass by 64,53 and $64 \%$ (Fig. 4a) and shoot biomass by 74, 62 and $83 \%$, respectively (Fig. 4b). Shoot height was also improved by the inoculation with strains B1 and B2 (Fig. 5a, b). These results were also observed in $\mathrm{Zn}$ - and Cd-treated plants which showed an enhancement of root and shoot biomass when rhizobacteria were inoculated if compared to uninoculated plants. Inoculation of strains B1 and B3 enhanced root biomass by 29 and $94 \%$ and shoot biomass by 62 and $120 \%$, respectively, at $500 \mathrm{mg} \mathrm{Zn} \mathrm{kg}^{-1}$ (Fig. 4). Similar results were obtained in Cd-treated plants, the rhizobacteria that better performed were strains B2 and B3, which
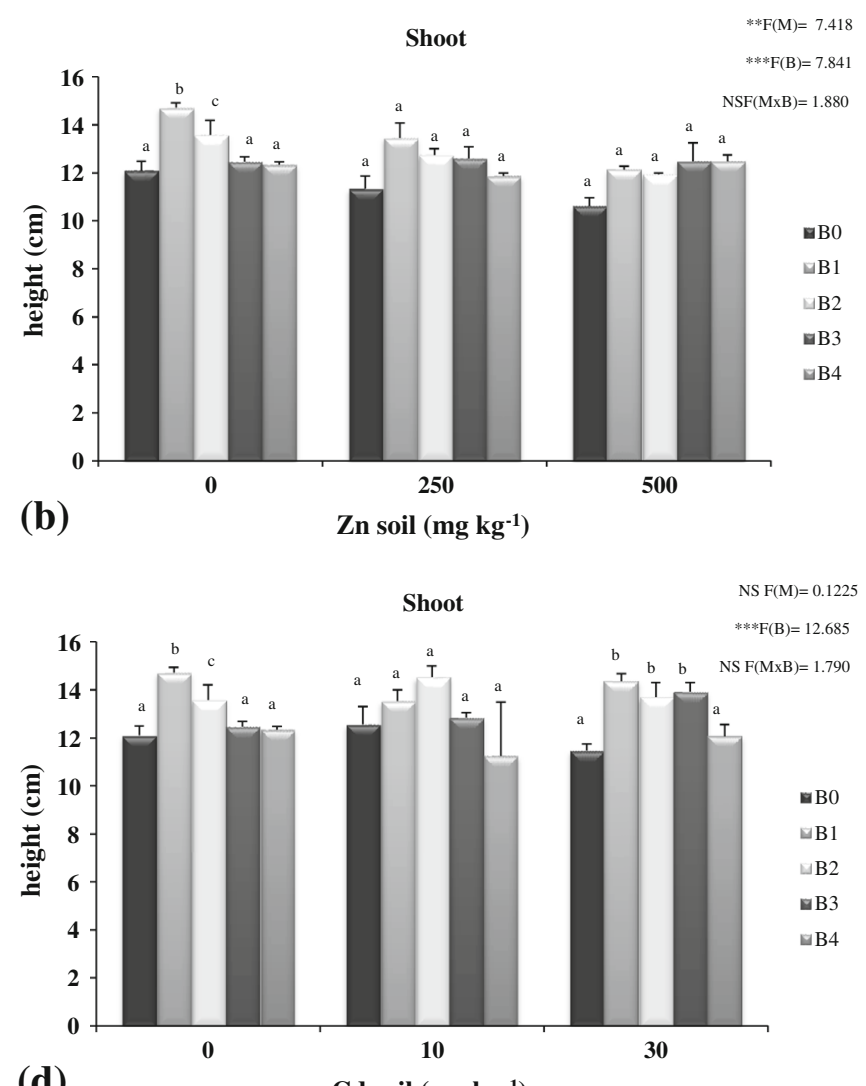

(d)

Cd soil (mg kg-1)

Means for the same metal concentration with different letters are significantly different from each other $(P<0.05)$ according to the Duncan test. For the root tissues, the $F$ values of one-way ANOVA are $F=3.016(P<0.05), F=8.920(P<0.01)$ and $F=0.963$ $(P>0.05)$ for 0,250 and $500 \mathrm{mg} \mathrm{Zn} \mathrm{kg}{ }^{-1}$ spiked soils, respectively, and $F=1,517(P>0.05)$ and $F=4.157(P<0.05)$ for 10 and $30 \mathrm{mg} \mathrm{Cd} \mathrm{kg}^{-1}$ spiked soils, respectively. For the shoot tissues, the $F$ values of one-way ANOVA are $F=10.379 \quad(P<0.001)$, $F=2.324(P>0.05)$ and $F=2.057(P>0.05)$ for 0,250 and $500 \mathrm{mg} \mathrm{Zn} \mathrm{kg}{ }^{-1}$ spiked soils, respectively, and $F=2.294(P>0.05)$ and $F=7.908(P<0.001)$ for 10 and $30 \mathrm{mg} \mathrm{Cd} \mathrm{kg}^{-1}$ spiked soils, respectively

promoted root biomass in both $\mathrm{Cd}$ concentrations. Strains B1, B2 and B3 also improved shoot biomass by 83, 137 and $66 \%$ in the presence of $10 \mathrm{mg} \mathrm{Cd} \mathrm{kg}^{-1}$ and by 39,58 and $56 \%$, respectively, in plants treated with $30 \mathrm{mg} \mathrm{Cd}$ $\mathrm{kg}^{-1}$ (Fig. 4d). Plant height in metal-spiked soils was also promoted by the inoculation with strain B1 in $250 \mathrm{mg} \mathrm{Zn}$ $\mathrm{kg}^{-1}$-exposed plants and strains B1, B2 and B3 in $30 \mathrm{mg}$ $\mathrm{Cd} \mathrm{kg}^{-1}$-treated plants (Fig. 5).

The four selected rhizobacteria produced high levels of IAA $\left(>31 \mathrm{mg} \mathrm{l}^{-1}\right)$ and exhibited ACC-deaminase activity (Figs. 2, 3), suggesting an involvement of these PGP traits on plant growth promotion under metal exposure. Belimov et al. (2005) showed a positive correlation between in vitro ACC-deaminase activity of the 
Table 3 The available and exchangeable $\mathrm{Zn}$ and $\mathrm{Cd}$ concentrations $\left(\mathrm{mg} \mathrm{kg}^{-1}\right)$ in uninoculated (B0) and inoculated soils (B1-EC 34; B2$1 \mathrm{AP} 2 ; \mathrm{B} 3-3 \mathrm{ZP} 2 ; \mathrm{B} 4-\mathrm{EC} 10)$ at the end of experiment

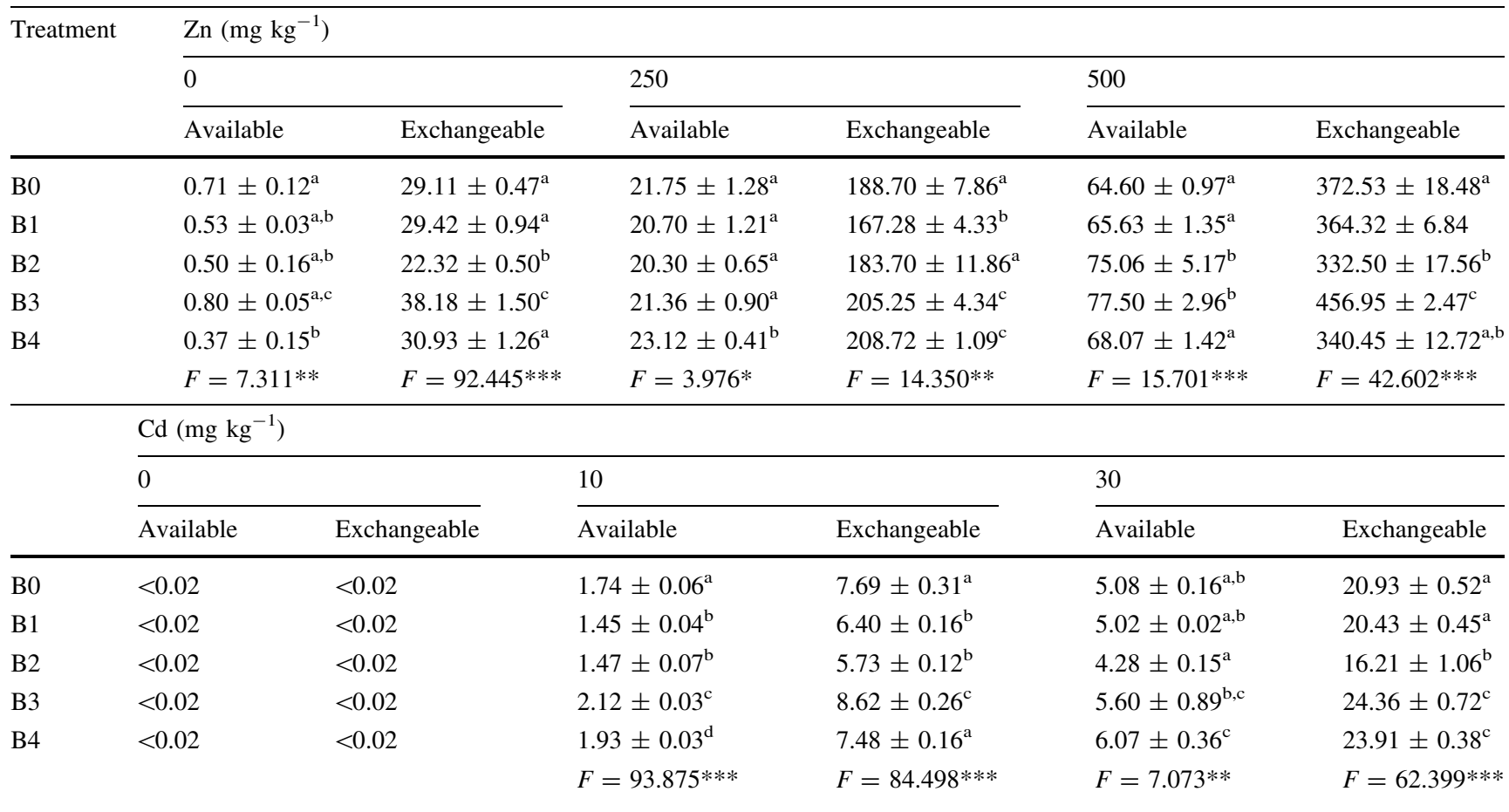

Results are expressed as mean $\pm \mathrm{SD}(n=4)$. A one-way ANOVA was performed for each concentration. Means in the same column with different letters are significantly different from each other $(P<0.05)$ according to the Duncan test

$N S$ nonsignificant at the level $P<0.05$; * significant at the level $P<0.05$; ** significant at the level $P<0.01$; *** significant at the level $P<0.001$

bacteria and their stimulating effect on root elongation of $B$. juncea seedlings in the presence of Cd. In fact, ACCdeaminase is of great importance when plants face high levels of metals, since the presence of these elements is normally encountered as a stress and plants respond by synthesizing more levels of ethylene, which in turn results in reduced plant growth.

Although a number of studies have demonstrated that bacterial inoculation in the rhizosphere of plant species may increase the efficiency of phytoremediation, since plant growth and survival in metal-contaminated soils are improved (He et al. 2009; Ma et al. 2009a; Madhaiyan et al. 2007; Vivas et al. 2006) to the best of our knowledge, this is the first research that reports on the potential of $R$. erythropolis (B1) to increase plant growth in $\mathrm{Zn}$ - and $\mathrm{Cd}$ contaminated soils.

The process of metal uptake and their accumulation by different plants depends on the concentration of the available metals in soils (Gupta and Sinha 2006). The available and exchangeable metal concentrations in rhizosphere soils determined at the end of the experiment are shown in Table 3. Available and exchangeable $\mathrm{Zn}$ concentrations ranged from 0.37 to $77.5 \mathrm{mg} \mathrm{Zn} \mathrm{kg}^{-1}$ and from 22.32 to
$456.95 \mathrm{mg} \mathrm{Zn} \mathrm{kg}^{-1}$, respectively, in the different $\mathrm{Zn}$ soil concentrations and between 1.45 and $6.07 \mathrm{mg} \mathrm{Cd} \mathrm{kg}^{-1}$ and from 5.73 to $24.36 \mathrm{mg} \mathrm{Cd} \mathrm{kg}^{-1}$ in the different $\mathrm{Cd}$ concentrations. In most cases, the inoculation with strains B3 and B4 significantly enhanced the available and exchangeable $\mathrm{Zn}$ and $\mathrm{Cd}$ concentrations in rhizosphere soils. For available metal concentrations, strain B4 showed better performance while for exchangeable concentrations, strain B3 seems to have a more pronounced effect on metal mobility in soils. Whiting et al. (2001) also reported that rhizobacteria inoculation increased water-soluble $\mathrm{Zn}$ concentration in soils and consequently enhanced $\mathrm{Zn}$ accumulation in shoots of Thlaspi caerulescens. Abou-Shanab et al. (2003) also showed the importance of PGPR on Ni solubilization in soils. Among the various metabolites produced by PGPR, the siderophores play a significant role in metal mobilization in soils, as these compounds produced by PGPR complexes with bivalent metal ions that can be assimilated by plants (Carrillo-Castañeda et al. 2003; Whiting et al. 2001). Our results highlight the potential of inoculating plants with siderophore-producing rhizobacteria to further improve their phytoextraction efficiency. 


\section{Conclusion}

The current study concluded that in vitro screening of rhizobacteria traits and growth promotion under axenic conditions can be an efficient tool to select rhizobacteria to use as bioinoculants in stress environmental situations. Inoculation of $T$. repens plants with selected PGPR significantly enhanced plant growth in the presence and absence of $\mathrm{Zn}$ and $\mathrm{Cd}$. The positive influence of PGPR inoculation on plant growth in metal-contaminated soils may be related to the multiple PGP traits of bacterial strains. However, it is not possible to determine exactly which bacterial mechanisms have a more pronounced impact in a given plant-microbe association. PGPR may positively influence plant growth in degraded environments using more than one trait, suggesting that plant growth stimulation is the net result of multiple mechanisms. The present work clearly indicates that some PGPR, such as $R$. erythropolis EC 34, Achromobacter sp. 1AP2 and Microbacterium sp. 3ZP2 may be used as bioinoculants and consequently constitute an attractive alternative to the chemical amendments used to improve phytoremediation efficiency.

Acknowledgments This work was supported by National Funds from FCT_Fundação para a Ciência e a Tecnologia through projects PTDC/AGR/CFL/111583/2009 and PEst-OE/EQB/LA0016/2013. S.I.A. Pereira wish to acknowledge a research grant from FCT (Ref. SFRH/BPD/65134/2009) and Fundo Social Europeu (Programa Operacional Potencial Humano (POPH), Quadro de Referência Estratégico Nacional (QREN)).

\section{References}

Abou-Shanab RA, Angle JS, Delorme TA, Chaney RL, van Berkum P, Moawad H, Ghanem K, Ghozlan HA (2003) Rhizobacterial effects on nickel extraction from soil and uptake by Alyssum murale. New Phytol 158:219-224

Ahmad F, Ahmad I, Khan MS (2008) Screening of free-living rhizospheric bacteria for their multiple plant growth promoting activities. Microbiol Res 163:173-181

Aina R, Palin L, Citterio S (2006) Molecular evidence for benzo[a]pyrene and naphthalene genotoxicity in Trifolium repens $\mathrm{L}$. Chemosphere 65:666-673

Andreazza R, Okeke BC, Lambais MR, Bortolon L, de Melo GWB, de Oliveira CFA (2010) Bacterial stimulation of copper phytoaccumulation by bioaugmentation with rhizosphere bacteria. Chemosphere 81:1149-1154

Barrutia O, Garbisu C, Hernandez-Allica J, Garcia-Plazaola JI, Becerril JM (2010) Differences in EDTA-assisted metal phytoextraction between metallicolous and non-metallicolous accessions of Rumex acetosa L. Environ Pollut 158:1710-1715

Belimov AA, Hontzeas N, Safronova VI, Demchinskaya SV, Piluzza G, Bullitta S, Glick BR (2005) Cadmium-tolerant plant growth-promoting bacteria associated with the roots of Indian mustard (Brassica juncea L. Czern.). Soil Biol Biochem $37: 241-250$
Blaylock MJ, Salt DE, Dushenkov S, Zakharova O, Gussman C, Kapulnik Y (1997) Enhanced accumulation of $\mathrm{Pb}$ in Indian mustard by soil applied chelating agents. Environ Sci Technol $31: 860-865$

Boyd RS (2010) Heavy metal pollutants and chemical ecology: exploring new frontiers. J Chem Ecol 36:46-58

Broos K, Uyttebroek M, Mertens J, Smolders E (2004) A survey of symbiotic nitrogen fixation by white clover grown on metal contaminated soils. Soil Biol Biochem 36:633-640

Cappuccino JC, Sherman N (1992) Negative staining. In: Cappuccino JC, Sherman N (eds) Microbiology: a laboratory manual, 3rd edn. Benjamin/Cummings PubCo, Redwood City, pp $125-179$

Carrillo-Castañeda G, Munoz JJ, Peralta-Videa JR, Gomez E, GardeaTorresdey JL (2003) Plant growth-promoting bacteria promote copper and iron translocation from root to shoot in alfalfa seedlings. J Plant Nutr 26:1801-1814

Castro IV, Ferreira EM, McGrath SP (2003) Survival and plasmid stability of rhizobial introduced into contaminated soil. Soil Biol Biochem 35:49-54

Cattelan AJ, Hartel PG, Fuhrmann JJ (1999) Screening for plant growth-promoting rhizobacteria to promote early soybean growth. Soil Sci Soc Am J 63:1670-1678

Chaudri A, McGrath S, Gibbs P, Chambers B, Carlton-Smith C, Bacon J, Campbell C, Aitken M (2008) Population size of indigenous Rhizobium leguminosarum biovar trifolii in longterm field experiments with sewage sludge cake, metal-amended liquid sludge or metal salts: effects of zinc, copper and cadmium. Soil Biol Biochem 40:1670-1680

Chen YP, Rekha PD, Arunshen AB, Lai WA, Young CC (2006) Phosphate solubilizing bacteria from subtropical soil and their tricalcium phosphate solubilizing abilities. Appl Soil Ecol 34:33-41

Dell'Amico E, Cavalca L, Andreoni V (2008) Improvement of Brassica napus growth under cadmium stress by cadmiumresistant rhizobacteria. Soil Biol Biochem 40:74-84

El-Tayeb MA, El-Enany AE, Ahmed NL (2006) Salicylic acid induced adaptive response to copper stress in sunflower (Helianthus annuus L.). Plant Growth Regul 50:191-199

Evangelou MWH, Bauer U, Ebel M, Schaeffer A (2007) The influence of EDDS and EDTA on the uptake of heavy metals of $\mathrm{Cd}$ and $\mathrm{Cu}$ from soil with tobacco Nicotiana tabacum. Chemosphere 68:345-353

Farina R, Beneduzi A, Ambrosini A, Campos SB, Lisboa BB, Wendisch V, Vargas LK, Passaglia LMP (2012) Diversity of plant growth-promoting rhizobacteria communities associated with the stages of canola growth. Appl Soil Ecol 55:44-52

Glick BR (2001) Phytoremediation: synergistic use of plants and bacteria to clean up the environment. Biotechnol Adv 21:383-393

Glick BR (2005) Modulation of plant ethylene levels by the bacterial enzyme ACC deaminase. FEMS Microbiol Lett 251:1-7

Glick BR (2010) Using soil bacteria to facilitate phytoremediation. Biotechnol Adv 28:367-374

Glick BR, Karaturovic DM, Newell PC (1995) A novel procedure for rapid isolation of plant growth promoting pseudomonads. Can J Microbiol 41:533-536

Gordon SA, Weber RP (1951) Colorimetric estimation of indoleacetic acid. Plant Physiol 26:192-195

Gupta AK, Sinha S (2006) Chemical fractionation and heavy metals accumulation in the plants of Sesamum indicum (L.) var. T55 grown on soil amended with tannery sludge: selection of single extractants. Chemosphere 64:161-173

Gupta CP, Dubey RC, Maheshwari DK (2002) Plant growth enhancement and suppression of Macrophomina phaseolina 
causing charcoal root of peanut by fluorescent Pseudomonas. Biol Fert Soils 35:399-405

Gupta P, Samant K, Sahu A (2012) Isolation of cellulose-degrading bacteria and determination of their cellulolytic potential. Int $\mathrm{J}$ Microbiol 2012:1-5

He LY, Chen ZJ, Ren GD, Zhang YF, Qian M, Sheng XF (2009) Increased cadmium and lead uptake of a cadmium hyperaccumulator tomato by cadmium-resistant bacteria. Eco Environ Saf 72:1343-1348

Kabata Pendias A, Pendias H (1992) Trace elements in soils and plants. CRC Press, Boca Raton

Khalid A, Arshad M, Zahir AA (2004) Screening plant growthpromoting rhizobacteria for improving growth and yield of wheat. J Appl Microbiol 96:473-480

Kloepper JW, Schroth MN (1978) Plant growth promoting rhizobacteria on radishes. In: Fourth international conference on plant pathogen bacteria. Angers, pp. 879-882

Li K, Ramakrishna W (2011) Effect of multiple metal resistant bacteria from contaminated lake sediments on metal accumulation and plant growth. J Hazard Mater 189:531-539

Luo S, Chen L, Chen J-L, Xiao X, Xu T, Wan Y, Rao C, Liu C, Liu Y, Lai C, Zeng G (2011) Analysis and characterization of cultivable heavy metal-resistant bacterial endophytes isolated from Cd-hyperaccumulator Solanum nigrum L. and their potential use for phytoremediation. Chemosphere 85:1130-1138

Ma Y, Rajkumar M, Freitas H (2009a) Inoculation of plant growth promoting bacterium Achromobacter xylosoxidans strain Ax10 for the improvement of copper phytoextraction by Brassica juncea. J Environ Manag 90:831-837

Ma Y, Rajkumar M, Freitas H (2009b) Isolation and characterization of Ni mobilizing PGPB from serpentine soils and their potential in promoting plant growth and Ni accumulation by Brassica spp. Chemosphere 75:719-725

Ma Y, Prasad MNV, Rajkumar M, Freitas H (2011) Plant growth promoting rhizobacteria and endophytes accelerate phytoremediation of metalliferous soils. Biotechnol Adv 29:248-258

Madhaiyan M, Poonguzhali S, Sa T (2007) Metal tolerating methylotrophic bacteria reduces nickel and cadmium toxicity and promotes plant growth of tomato (Lycopersicon esculentum L.). Chemosphere 69:220-228

Manier N, Deram A, Broos K, Denayer F, Van Haluwyn C (2009) White clover nodulation index in heavy metal contaminated soils: a potential bioindicator. J Environ Qual 38:685-692

Marques APGC, Rangel AOSS, Castro PML (2009) Remediation of heavy metal contaminated soils: phytoremediation as a potentially promising clean-up technology. Crit Rev Environ Sci Technol 39:622-654

Marques APGC, Pires C, Moreira H, Rangel AOSS, Castro PML (2010) Assessment of the plant growth promotion abilities of six bacterial isolates using Zea mays as indicator plant. Soil Biol Biochem 42:1229-1235

Marques APGC, Moreira H, Franco AR, Rangel AOSS, Castro PML (2013) Inoculating Helianthus annuus (sunflower) grown in zinc and cadmium contaminated soils with plant growth promoting bacteria: effects on phytoremediation strategies. Chemosphere 92:74-83

Nautiyal CS (1999) An efficient microbiological growth medium for screening phosphate solubilizing microorganisms. FEMS Microbiol Lett 170:265-270

Oliveira RS, Dodd JC, Castro PML (2001) The mycorrhizal status of Phragmites australis in several polluted soils and sediments of an industrialised region of Northern Portugal. Mycorrhiza 10:241-247
Patten CL, Glick BR (2002) Role of Pseudomonas putida indoleacetic acid in development of the host plant root system. Appl Environ Microbiol 8:3795-3801

Penrose DM, Glick BR (2003) Methods for isolating and characterizing ACC deaminase-containing plant growth-promoting rhizobacteria. Physiol Plant 118:10-15

Pilon-Smits E (2005) Phytoremediation. Annu Rev Plant Biol 56:15-39

Pires C (2010) Bacteria in heavy metal contaminated soil: diversity, tolerance and use in remediation systems. Ph.D. dissertation, Cranfield University

Rajkumar M, Freitas H (2008) Effects of inoculation of plant-growth promoting bacteria on $\mathrm{Ni}$ uptake by Indian mustard. Bioresour Technol 99:3491-3498

Rajkumar M, Prasad MNV, Freitas H (2010) Potential of siderophoreproducing bacteria for improving heavy metal phytoextraction. Trends Biotechnol 28:142-149

Saharan BS, Nehra V (2011) Plant growth promoting rhizobacteria: a critical review. Life Sci Med Res 21:1-30

Sahu GK, Sindhu SS (2011) Disease control and plant growth promotion of green gram by siderophore producing Pseudomonas sp. Res J Microbiol 6:735-749

Saleh SS, Glick BR (2001) Involvement of gasS and pros in enhancement of the plant growth-promoting capabilities of Enterobacter cloacae CAL2 and UW4. Can J Microbiol 47:698-705

Schwyn B, Neilands JB (1987) Universal chemical assay for the detection and determination of siderophores. Anal Biochem 160:47-56

Shahzad SM, Khalid A, Arshad M, Rehman K (2010) Screening rhizobacteria containing ACC-deaminase for growth promotion of chickpea seedlings under axenic conditions. Soil Environ 29:38-46

Sheng XF, Xia JJ (2006) Improvement of rape (Brassica napus) plant growth and cadmium uptake by cadmium-resistant bacteria. Chemosphere 64:1036-1042

Smibert RM, Krieg NR (1994) Phenotypic characterization. In: Gerhardt P, Murray RGE, Wood WA, Krieg NR (eds) Methods for general and molecular bacteriology. American Society for Microbiology, Washington, pp 611-651

Tsezos M (2009) Metal-microbes interactions: beyond environmental protection. Adv Mater Res 71-73:527-532

Ultra VU, Yano A, Iwasaki K, Tanaka S, Kang YM, Sakurai K (2005) Influence of chelating agent addition on copper distribution and microbial activity in soil and copper uptake by brown mustard (Brassica juncea). Soil Sci Plant Nutr 51:193-202

van Loon LC (2007) Plant responses to plant growth promoting rhizobacteria. Eur J Plant Pathol 119:243-254

Vasseur L, Fortin MJ, Cyr J (1998) Clover and cress as indicator species of impacts from limed sewage sludge and landfill wastewater land application. Sci Total Environ 217:231-239

Vessey JK (2003) Plant growth promoting rhizobacteria as biofertilizers. Plant Soil 255:571-586

Vivas A, Biro B, Ruíz-Lozanoa JM, Azcon R (2006) Two bacterial strains isolated from a $\mathrm{Zn}$-polluted soil enhance plant growth and mycorrhizal efficiency under $\mathrm{Zn}$ toxicity. Chemosphere 52:1523-1533

Wallinga I, Vark W, Houba VJG, Lee JJ (1989) Plant analysis procedures. Syllabus, Department of Soil Science and Plant Nutrition, Wageningen Agricultural University, Wageningen 
Whiting NS, de Souza PM, Terry N (2001) Rhizosphere bacteria mobilize $\mathrm{Zn}$ for hyperaccumulation by Thlaspi caerulescens. Environ Sci Technol 35:3144-3150

Xie H, Pasternak JJ, Glick BR (1996) Isolation and characterization of mutants of the plant growth-promoting rhizobacterium Pseudomonas putida GR-122 that overproduce indole acetic acid. Curr Microbiol 32:67-71
Zaidi A, Khan MS (2007) Stimulatory effect of dual inoculation with phosphate solubilizing microorganisms and arbuscular mycorrhizal fungus on chickpea. Aust J Exp Agric 47:1014-1022 